\title{
URINARY EXCRETION OF GONADOTROPHINS WITH PARTICULAR REFERENCE TO CHILDREN
}

\author{
BY \\ W. FITSCHEN* and BARBARA E. CLAYTON \\ From the Department of Chemical Pathology, Hospital for Sick Children, Great Ormond Street, London
}

(RECEIVED FOR PUBLICATION JUNE 24, 1964)

Until recently there has been fairly general agreement that gonadotrophins are not detectable in the urine during childhood. Table 1 summarizes the results of previous investigators in this field. Of the early workers, only Catchpole and Greulich (1943) have, in serial determinations, detected gonadotrophins in young girls. More recently, studies performed on pools of urine have indicated that gonadotrophins are excreted as early as 3 to 5 years in boys (Knappe, Dörner, and Stahl, 1961); and possibly in girls (Carletti and Kehyayan, 1962a, b), though the latter workers used combined pools for boys and girls. Full experimental details have not been published to substantiate the claim of Minkina (1961) that gonadotrophin excretion in girls aged 1-3 years is very much higher than in girls at or near the menarche.

In 1960, Landau, Schwartz, and Soffer suggested that children's urine contained an inhibitor for gonadotrophins. They observed inhibition of the response when extracts of children's urine were combined with extracts of known gonadotrophic potency. A later report (Soffer, Futterweit, and Salvaneschi, 1961) substantiated these observations, particularly with regard to children under 6 years of age. Soffer, Salvaneschi, and Futterweit (1962) claimed to have detected a factor in all age-groups that inhibited the action of human chorionic gonadotrophin (HCG), but failed to inhibit the uterine response to oestrone.

In view of the paucity both of positive results in young children and of results in terms of standard reference preparations, it seemed of value to investigate again the excretion of gonadotrophins in childhood. This was an essential preliminary to assessing gonadotrophin excretion in pathological conditions.

The increase in uterine weight of the immature mouse is regarded as the most sensitive end-point for the routine bio-assay of total urinary gonadotrophins (Rosemberg, 1961). Though methods commonly

* Present address: National Chemical Research Lab., P.O. Box 395, Pretoria, South Africa. Requests for reprints should be sent to Dr. B. Clayton. employed have involved multiple injections over a three-day period (Loraine and Brown, 1959), it was thought that the use of a single injection method such as that of Claringbold and Lamond (1957) might afford a more sensitive assay because a threshold dose would not be subdivided into sub-threshold doses. Since Lamond and Claringbold (1958) failed to demonstrate synergism between various gonadotrophins in an assay depending on the early response of the uterus after a single injection, it is likely that such an assay will more accurately reflect the total gonadotrophin present (follicle stimulating hormone (FSH) and luteinizing hormone (LH)). Brown and Billewicz (1962) showed that if enough time were allowed for growth and differentiation of the ovary (as in the usual three-day assay), the same uterine response was achieved by a wide variation in the total dose of gonadotrophin, using different proportions of FSH and LH. Thus extracts containing unknown proportions of FSH and LH could not be reliably assayed in an assay allowing extensive differentiation of the ovary, except at very low levels when the uterine response to FSH and $\mathrm{LH}$ was similar. Taking these facts into account, a more sensitive method for the assay of total urinary gonadotrophins has been developed.

In addition, luteinizing hormone ( $\mathrm{LH}$ ) has been estimated in children's urine using the ovarian ascorbic acid depletion assay, as modified by Schmidt-Elmendorff and Loraine (1962).

\section{Material and Methods}

Hormones Used in Assays. These are listed below. (1). Human menopausal gonadotrophin. International Reference Preparation (I.R.P.) (Bull. Wld Hlth Org., 1960).

(2). Human chorionic gonadotrophin (HCG). The preparation used was gonadotrophin LH (Paines and Byrne, Ltd.).

(3). Human menopausal gonadotrophin (LAB-G). This preparation was extracted and purified from postmenopausal urine by the method of Loraine and Brown (1959). It was assayed in terms of I.R.P. using the modification of the mouse uterus method as described in this paper, and the following data were obtained. 
TABLE 1

GONADOTROPHINS IN THE URINE OF CHILDREN

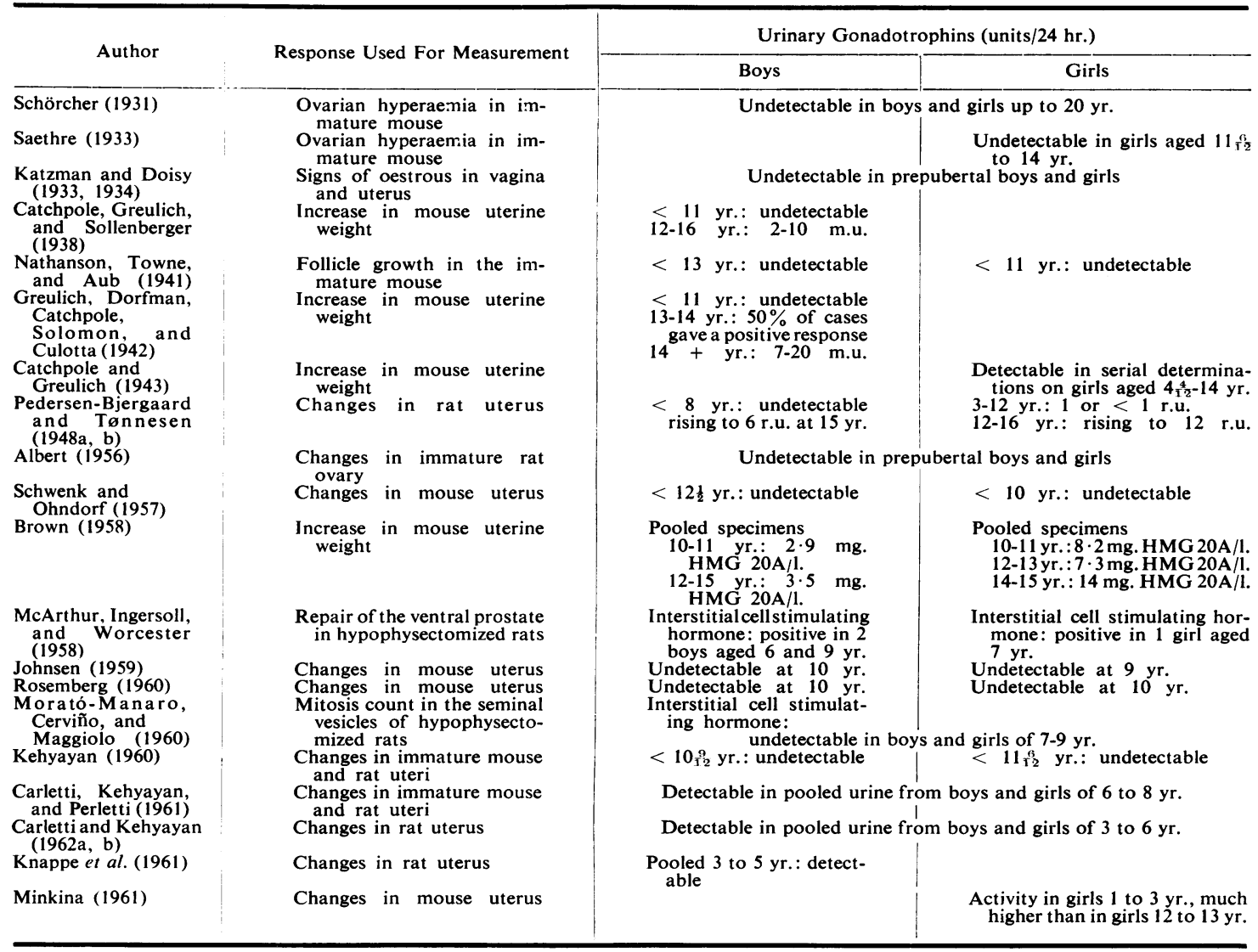

m.u. = mouse unit; r.u. = rat unit.

Relative potency: $1.00 \mathrm{mg}$. LAB-G $=0.77 \mathrm{mg}$. I.R.P. Errors: Fiducial limits 0.60 to $0.93 \mathrm{mg}$. I.R.P. $(\mathrm{p}=0.95)$. Index of precision, $\lambda=0 \cdot 164$.

Validity test: $\quad \mathrm{t}$ test for parallelism, $\mathrm{t}=0 \cdot 216$ (i.e. no significant deviation).

Index of significance of slope $b: \mathrm{g}=0.083$ (i.e.

(4). Luteinizing hormone (NIH-LH-S-1).*

Extraction Method. Extracts were prepared from complete 24-hour urine specimens (or multiples thereof) and from pooled random specimens of urine by the kaolin-acetone method of Albert (1956) as modified by

* Supplied by the Endocrinology Study Section, National Institutes of Health, Washington D.C., U.S.A., and prepared from sheep pituitary hormone.
Borth, Lunenfeld, and Menzi (1961), but using the adjustments of $p \mathbf{H}$ as described by Loraine and Brown (1959). Extracts were purified by salt-ethanol fractionation (stage 2, Albert, Kobi, Leiferman, and Derner, 1961).

For the assay of total urinary gonadotrophins and luteinizing hormone, the extracts were dissolved in $0.1 \mathrm{M}$ borate buffer $(p \mathrm{H} \mathrm{9)}$ and $0.9 \% \mathrm{NaCl}$ respectively, so that each mouse or rat received 0.25 or $0.2 \mathrm{ml}$., respectively.

$0 \cdot 1 \mathrm{M}$ borate buffer: $100 \mathrm{ml}$. boric acid $(6 \cdot 18 \mathrm{~g}$./1.) mixed with $42 \cdot 6 \mathrm{ml}$. sodium hydroxide $(4 \mathrm{~g}$. /1.).

Animals. Female mice, strain T/o, 19 to 22 days old and weighing 9 to $11 \mathrm{~g}$., and female Sprague-Dawley rats aged 25 days and weighing 65 to $80 \mathrm{~g}$. were obtained from Animal Suppliers (London) Ltd. They were maintained on a synthetic diet prepared from casein, lard, sucrose, salt mixture, and vitamins (H. Saunders, 1958, personal communication). 
Statistical Evaluation of Results. Slope (b), relative potency, fiducial limits of error, index of precision $(\lambda)$, index of significance of regression, and validity of parallelism were calculated according to Gaddum (1953a, b) and Borth, Diczfalusy, and Heinrichs (1957).

Genital and Secondary Sex Character Rating. This was assessed according to Tanner (1955), but for various reasons it was not possible to do this in every child.

\section{Bio-assay of Total Urinary Gonadotrophins}

Extracts were assayed by a modification of the mouse uterus test of Klinefelter, Albright, and Griswold (1943).

Each mouse received $0 \cdot 1$ i.u. HCG subcutaneously in $0.1 \mathrm{ml} .0 .9 \% \mathrm{NaCl} ; 24$ hours later the standard or extract was administered as a single injection, and the mice were killed by decapitation 40 to 44 hours later. The uteri were dissected out, placed in Bouin's fluid for 24 hours, cleaned, blotted dry, and weighed to the nearest $1 \mathrm{mg}$. on a torsion balance.

The design of the assays is described in the sections relating to the clinical investigations performed, doseresponse curves for Standard being constructed using total dosages of LAB-G of 0.39 to $1.34 \mathrm{mg}$./mouse.

\section{Development of Method.}

(1). Determination of the time of maximum response after a single injection of $L A B-G$ : in three separate investigations, a total of 68 mice were injected with $1.0 \mathrm{mg}$. LAB-G and killed in groups of four at intervals between 10 and 70 hours after injection.

The uterine responses obtained are shown in Fig. 1.
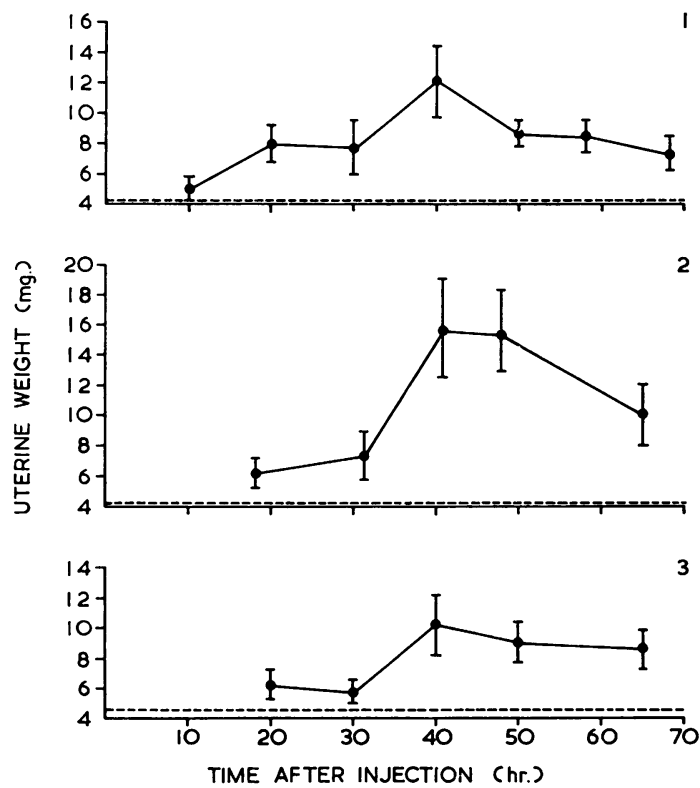

FIG. 1.-Determination of the time of maximum response after a single injection of LAB-G. Three separate investigations were performed. Each point $=$ mean for 4 mice \pm standard deviation. control uterine weight.
TABLE 2

UTERINE WEIGHTS 40 TO 44 HOURS AFTER SINGLE INJECTION OF HCG

\begin{tabular}{c|c}
\hline $\begin{array}{c}\text { Dose per Mouse } \\
\text { (i.u.) }\end{array}$ & $\begin{array}{c}\text { Mean Uterine Weight } \\
\text { (mg. } \pm \text { S.E.M.) }\end{array}$ \\
\hline $0 \cdot 10$ & $3 \cdot 8 \pm 0 \cdot 26$ \\
$0 \cdot 25$ & $5 \cdot 5 \pm 1 \cdot 07$ \\
$0 \cdot 50$ & $6 \cdot 0 \pm 0 \cdot 74$ \\
$0 \cdot 75$ & $7 \cdot 3 \pm 0 \cdot 71$ \\
$1 \cdot 0$ & $9 \cdot 7 \pm 0 \cdot 32$ \\
Saline & $4 \cdot 0 \pm 0 \cdot 32$ \\
\hline
\end{tabular}

The maximum response occurred at 40 hours, and in all subsequent experiments involving single injections the mice were killed 40 to 44 hours after injection of the material to be assayed.

(2). Comparison of the size of the uterine response after single, as compared with multiple, injections: $0.60 \mathrm{mg}$. LAB-G was injected into 2 groups of 8 mice. Group A received the total amount divided into 5 doses; 2 injections were given on both the first and second days, and one on the third day. The mice were killed 72 hours after the first injection. Group B received the total amount as a single injection, and the mice were killed 40 to 44 hours later. A control group of 5 mice, injected as in Group B, received saline only.

The mean uterine weights ( \pm standard errors of the means) were as follows. Group A: $4.7 \pm 0.4 \mathrm{mg}$; Group B: $7.6 \pm 0.3 \mathrm{mg}$; and saline controls: $4.4 \pm$ $0.4 \mathrm{mg}$.

The uterine weights in Group B were significantly greater than those of Group A $(p<0.005)$.

(3). Determination of a satisfactory priming dose of $H C G$ : mice, in groups of 5 , were given single injections of HCG in doses of $0 \cdot 10$ to $1 \cdot 0$ i.u. per mouse; they were killed 40 to 44 hours later. The uterine weights are shown in Table 2 . There was a significant increase $(\mathrm{p}=0.05)$ in uterine weight with 0.50 but not 0.25 i.u. per mouse, as compared with the saline-injected controls. The threshold dose therefore lay between 0.25 and 0.50 i.u. per mouse.

(4). Effect of the length of time between the priming dose of $H C G$ and injection of the test substance: groups of 5

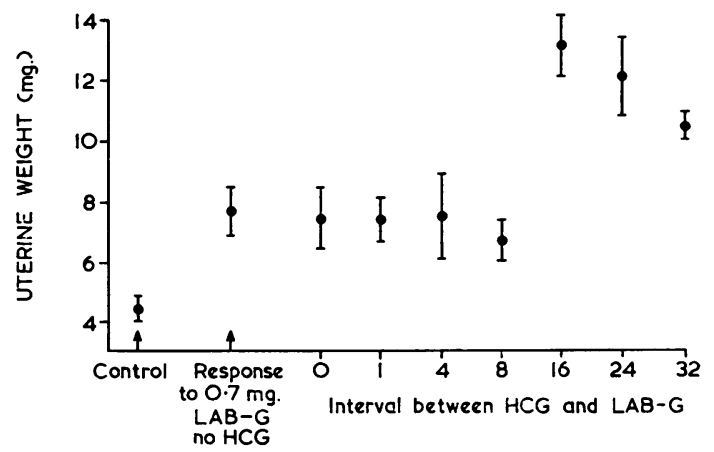

FIG. 2.-Effect of the length of time between the priming dose of HCG and a single injection of LAB-G. All points are means for 5 mice \pm standard deviation. 
TABLE 3

EFFECT OF SIZE OF PRIMING DOSE OF HCG

\begin{tabular}{|c|c|c|c|}
\hline $\begin{array}{c}\text { Dose of } \\
\text { HCG } \\
\text { (i.u./mouse) }\end{array}$ & $\begin{array}{c}\text { Dose of } \\
\text { LAB-G } \\
\text { (mg./mouse) }\end{array}$ & \multicolumn{2}{|c|}{ Uterine Weight \pm S.E.M. } \\
\hline $\begin{array}{l}0.05 \\
0 \cdot 10\end{array}$ & $\begin{array}{l}0.7 \\
0.7\end{array}$ & $\begin{array}{r}8 \cdot 8 \pm 1 \cdot 3 \\
11 \cdot 4 \pm 1 \cdot 6\end{array}$ & $\begin{array}{l}\text { Not significantly } \\
\text { different } \\
(\mathrm{p} \simeq 0.15)\end{array}$ \\
\hline $\begin{array}{l}0 \cdot 10 \\
0 \cdot 25\end{array}$ & $\begin{array}{l}1 \cdot 0 \\
1 \cdot 0\end{array}$ & $\left.\begin{array}{l}14 \cdot 5 \pm 1 \cdot 9 \\
13 \cdot 7 \pm 1 \cdot 5\end{array}\right)$ & $\begin{array}{l}\text { Not significantly } \\
\text { different } \\
(\mathrm{p} \simeq 0.15)\end{array}$ \\
\hline
\end{tabular}

mice were primed with $0 \cdot 10$ i.u. $\mathrm{HCG}$ at intervals of 0 to 32 hours before a standard dose of $0.70 \mathrm{mg}$. LAB-G. The results are shown in Fig. 2. Maximum potentiation of response was achieved when the interval between $\mathrm{HCG}$ and LAB-G was 16 and 24 hours. In all subsequent assays, 24 hours was used as the priming interval.

(5). Effect of the magnitude of the priming dose of $\mathrm{HCG}$ : groups of 5 mice were primed with $0.05,0.10$, or $0 \cdot 25$ i.u. HCG, and 24 hours later 0.7 or $1.0 \mathrm{mg}$. LAB-G was injected. The results, given in Table 3, showed that variations in the size of the priming dose tested did not affect the uterine responses significantly. $0 \cdot 10 \mathrm{i} . \mathrm{u}$. HCG was selected as the priming dose in all subsequent experiments.

(6). To study three different schedules of injection: using 5 mice per group, LAB-G was injected in a total dosage of 0.2 to $1.0 \mathrm{mg}$. per mouse according to one of three schedules.

Schedule A. A single injection of LAB-G was given to mice pretreated 24 hours previously with $0 \cdot 1$ i.u. HCG. The mice were killed 40 to $\mathbf{4 4}$ hours after the last injection. Schedule B. LAB-G was given in a single injection to untreated mice which were killed 40 to 44 hours later.

Schedule $C$. The total dose of LAB-G was divided into five, and administered to untreated mice. Two injections were given on both the first and second days, and one during the third day, and the mice were killed 72 hours after the first injection.

The results are given in Table 4 , and recorded diagrammatically in Fig. 3, in which the logarithm of the total dose of LAB-G is plotted against the percentage increase in uterine weight, the control uterine weight being taken as $100 \%$.

It was concluded that maximum sensitivity and the steepest dose-response line at low doses was achieved by using a single injection of LAB-G following pretreatment

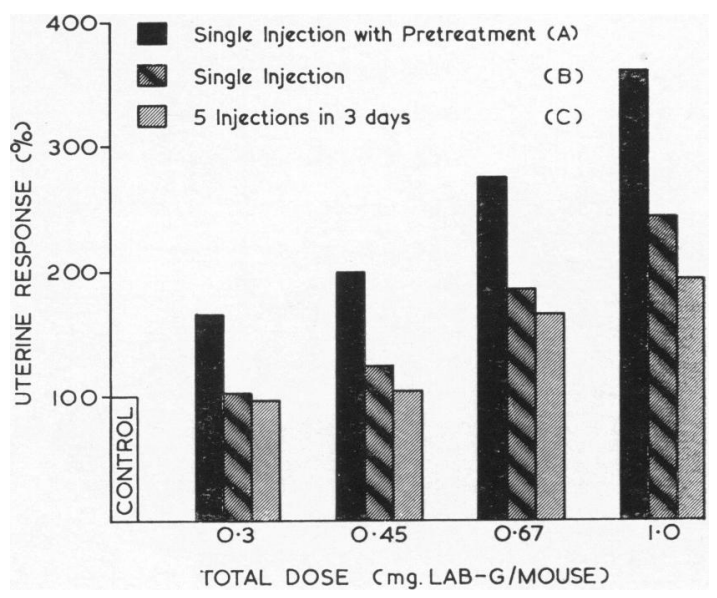

FIG. 3.-The effect of three different schedules of injection. Tl:e logarithm of the total dose of LAB-G is plotted against the percentage increase in uterine weight, the control uterine weight being taken as $100 \%$.

with HCG. Schedule (a) has been used in all subsequent assays of total urinary gonadotrophin.

(7). Ovarian histology with $H C G, L A B-G$, and $H C G+$ $L A B-G$ : mice were injected and killed in groups of 4 according to the schedule illustrated in Fig. 4.

On sacrifice, the ovaries were fixed in $10 \%(\mathrm{v} / \mathrm{v})$ formalin in saline, sectioned, and stained with haematoxylin and eosin. Ovaries from mice injected with $0 \cdot 1$ i.u. HCG only, showed slight follicular ripening at all time intervals compared with those from saline-injected controls. A similar but more marked effect was obtained with LAB-G at 24 hours. At 48 hours after LAB-G, extensive follicular stimulation and luteinization was seen. No difference in ovarian histology was noted between the groups injected with LAB-G and killed after the same time interval, with and without pretreatment with HCG. (8). Accuracy: children's urine, in which no total gonadotrophin activity could be detected, was pooled. $20.0 \mathrm{mg}$. LAB-G dissolved in $2.0 \mathrm{ml} .0 \cdot 1 \mathrm{M}$ borate buffer was added to each of three 1 litre aliquots. These samples and a further 1 litre to which no LAB-G had been added, were extracted and purified. The purified extract from each sample was dissolved in $2.5 \mathrm{ml} .0 \cdot 1 \mathrm{M}$ borate buffer

TABLE 4

UTERINE RESPONSES USING THREE DIFFERENT SCHEDULES FOR INJECTION

\begin{tabular}{|c|c|c|c|c|c|}
\hline \multirow{2}{*}{$\begin{array}{c}\text { Total } \\
\text { Dose } \\
\text { LAB-G } \\
\text { (mg./mouse) }\end{array}$} & \multicolumn{3}{|c|}{$\begin{array}{c}\text { Uterine Response (mg. } \pm \text { S.E.M.) } \\
\text { Schedule }\end{array}$} & \multicolumn{2}{|c|}{$\begin{array}{c}\text { Probability that Schedules Give } \\
\text { Different Responses }\end{array}$} \\
\hline & $\mathbf{A}$ & B & $\mathbf{C}$ & $\begin{array}{l}\text { A as compared } \\
\text { with B }\end{array}$ & $\begin{array}{l}\text { A as compared } \\
\text { with C }\end{array}$ \\
\hline $\begin{array}{l}0 \\
0 \cdot 3 \\
0 \cdot 45 \\
0 \cdot 67 \\
1 \cdot 00\end{array}$ & $\begin{array}{r}4.0 \pm 0.4 \\
6.6 \pm 0.7 \\
8.0 \pm 0.5 \\
11.0 \pm 1.6 \\
14.4 \pm 2.0\end{array}$ & $\begin{array}{l}4.2 \pm 0.2 \\
5.0 \pm 0.5 \\
7.4 \pm 0.5 \\
9.8 \pm 0.9\end{array}$ & $\begin{array}{l}3 \cdot 8 \pm 0.2 \\
4 \cdot 2 \pm 0.8 \\
6 \cdot 6 \pm 1 \cdot 6 \\
7.8 \pm 1 \cdot 2\end{array}$ & $\begin{array}{l}\simeq 0.01 \\
\simeq 0.002 \\
\simeq 0.025 \\
\simeq 0.025\end{array}$ & $\begin{aligned} & \simeq 0.005 \\
& \simeq 0.005 \\
\simeq & 0.025-0.05 \\
& \simeq 0.01\end{aligned}$ \\
\hline
\end{tabular}




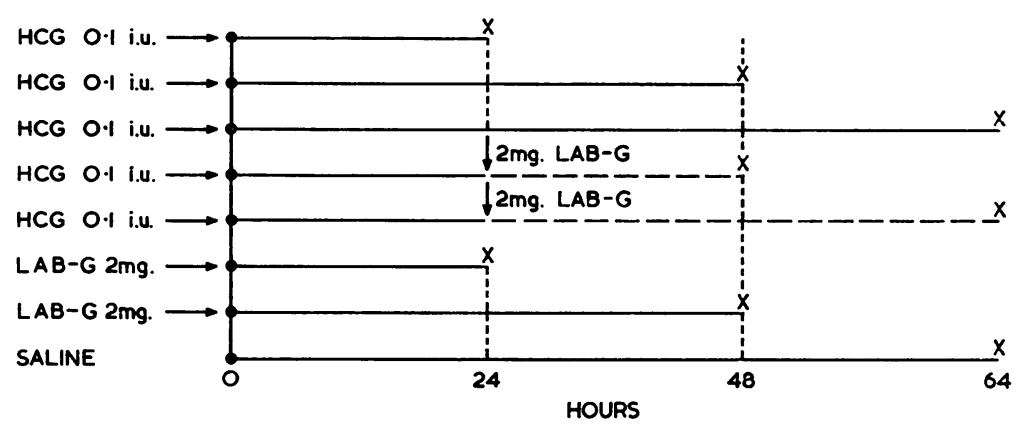

FIG. 4.-The schedule for injecting and killing the mice. $\quad \times=$ killed; $\rightarrow=$ injection.

and assayed against LAB-G using 10 mice per group and a $(2+1)$ assay design.

No gonadotrophic activity was detected in the urine containing no added LAB-G. Recoveries of added LAB-G are shown in Table 5.

Four samples of LAB-G, each of $10.0 \mathrm{mg}$., were purified by the salt-ethanol fractionation procedure, and assayed against LAB-G itself using 5 mice per group and a $(2+1)$ assay design. Results are shown in Table 5.

TABLE 5

\begin{tabular}{|c|c|c|}
\hline $\begin{array}{c}\text { Recovery } \\
\text { (LAB-G in mg.) }\end{array}$ & $\begin{array}{l}95 \% \text { Fiducial } \\
\text { Limits }\end{array}$ & $\begin{array}{l}\text { Percentage } \\
\text { Recovery }\end{array}$ \\
\hline \multicolumn{3}{|c|}{ 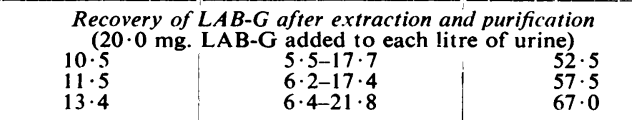 } \\
\hline 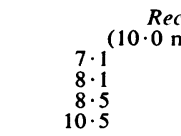 & $\begin{array}{l}\text { LAB-G after } \\
\text { ples of LAB-G } \\
2 \cdot 9-12 \cdot 5 \\
3 \cdot 3-14 \cdot 9 \\
4 \cdot 2-14 \cdot 3 \\
4 \cdot 5-18 \cdot 1\end{array}$ & $\begin{array}{l}\text { (fied) } \\
71 \\
81 \\
85 \\
105\end{array}$ \\
\hline
\end{tabular}

In view of the number of steps involved and the errors inherent in the bio-assay, the recoveries were considered reasonably satisfactory.

(9). Precision: a pool of 4 litres of urine from normal men was divided into 4 aliquots which were extracted and purified. Each extract was assayed against LAB-G using a $(2+1)$ assay design and 10 mice per group. The results, shown in Table 6 , indicated satisfactory reproducibility.

The precision of the assay was satisfactory, Gaddum's $\lambda$ being $<0.2$ except on two occasions. Fiducial limits for assays are given in the relevant sections on clinical application of the method.

(10). Toxicity of the purified extract: no toxic effects were observed when purified extracts (equivalent to a 24-hour urine output) from children and adults were injected into individual mice. It was frequently possible to inject twice the equivalent of a 24-hour urine from a child into each mouse.
TABLE 6

REPRODUCIBILITY OF METHOD FOR ASSAYING TOTAL URINARY GONADOTROPHINS

\begin{tabular}{c|c|c|c}
\hline $\begin{array}{c}\text { Urine } \\
\text { Sample }\end{array}$ & $\begin{array}{c}\text { Total } \\
\text { Gonadotrophins } \\
\text { in }\end{array}$ & $\begin{array}{c}\text { Fiducial Limits of } \\
\text { Assay (p=0.95) }\end{array}$ & $\lambda$ \\
\hline 1 & LAB-G (mg./1.) & & \\
\hline 2 & $3 \cdot 56$ & $1 \cdot 47-6 \cdot 25$ & $0 \cdot 139$ \\
3 & $3 \cdot 35$ & $1 \cdot 36-6 \cdot 08$ & $0 \cdot 151$ \\
4 & 3.92 & $1 \cdot 89-6 \cdot 57$ & $0 \cdot 135$ \\
& 4.04 & $1 \cdot 71-7 \cdot 19$ & $0 \cdot 151$ \\
\hline
\end{tabular}

Mean $=3 \cdot 72+$ S.E.M. $0 \cdot 15$

(11). Sensitivity: over a period of two years, the mean control uterine weight of mice which received $0 \cdot 1$ i.u. HCG only, was consistently between 3.5 and $4.5 \mathrm{mg}$. Data with respect to three standard curves, selected at random from the results available, are shown in Table 7 .

\section{Bio-assay of Luteinizing Hormone in Urine}

Luteinizing hormone in urine was assayed by the method of ovarian ascorbic acid depletion, as modified by Schmidt-Elmendorff and Loraine (1962) using NIH-LH as a reference preparation. Symmetrical four-point assays with two dose levels of standard (S) and unknown (U) respectively were used, the log dose interval being $\log _{10} 3(0 \cdot 4771): 4$ or 5 rats ( 8 or 10 ovaries) were used at each dose.

TABLE 7

DATA ON THREE STANDARD CURVES

\begin{tabular}{|c|c|c|c|}
\hline \multirow{2}{*}{$\begin{array}{c}\text { Dose/ } \\
\text { mouse } \\
\text { (mg. } \\
\text { LAB-G) }\end{array}$} & \multicolumn{3}{|c|}{$\begin{array}{c}\text { Mean Uterine Response } \\
\text { for Group of } 5 \text { Mice } \pm \text { Standard Deviation }\end{array}$} \\
\hline & Curve 1 & Curve 2 & Curve 3 \\
\hline $\begin{array}{c}0 \cdot 39 \\
0 \cdot 59 \\
0 \cdot 88 \\
1 \cdot 34 \\
\text { Saline } \\
\text { b }\end{array}$ & $\begin{array}{c}11 \cdot 3 \pm 2 \cdot 1 \\
17 \cdot 1 \pm 4 \cdot 1 \\
17 \cdot 7 \pm 6 \cdot 2 \\
27 \cdot 1 \pm 8 \cdot 7 \\
4 \cdot 5 \pm 1 \cdot 0 \\
28 \cdot 24\end{array}$ & $\begin{array}{c}10.6 \pm 1.9 \\
14.2 \pm 3.8 \\
17.9 \pm 5.9 \\
27.6 \pm 7.0 \\
5.7 \pm 0.9 \\
30.75\end{array}$ & $\begin{array}{c}7 \cdot 5 \pm 2 \cdot 9 \\
10 \cdot 5 \pm 3 \cdot 1 \\
12 \cdot 6 \pm 2 \cdot 9 \\
20 \cdot 6 \pm 6 \cdot 1 \\
5 \cdot 7 \pm 1 \cdot 2 \\
24 \cdot 34\end{array}$ \\
\hline
\end{tabular}


TABLE 8

ASSAYS OF TOTAL URINARY GONADOTROPHIN EXCRETION

\begin{tabular}{|c|c|c|c|c|c|c|}
\hline Urine & $\begin{array}{l}\text { Gonadotrophin } \\
\text { Excretion per } 24 \\
\text { hr. (mg. I.R.P.) }\end{array}$ & $\begin{array}{c}\begin{array}{c}\text { Fiducial } \\
\text { Limits }\end{array} \\
(p=0.95)\end{array}$ & $\lambda$ & $\mathbf{g}$ & & $\mathbf{p}$ \\
\hline 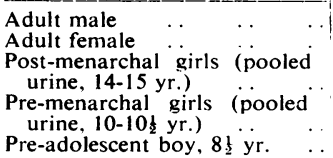 & $\begin{array}{l}6 \cdot 1 \\
6 \cdot 7\end{array}$ & $\begin{array}{l}4 \cdot 5-8 \cdot 1 \\
4 \cdot 5-9 \cdot 9\end{array}$ & $\begin{array}{l}0 \cdot 12 \\
0 \cdot 13 \\
0 \cdot 15 \\
0 \cdot 20 \\
0 \cdot 23\end{array}$ & $\begin{array}{l}0 \cdot 1410 \\
0 \cdot 1490\end{array}$ & $\begin{array}{l}0 \cdot 320 \\
0 \cdot 230\end{array}$ & $\begin{array}{l}0 \cdot 7-0 \cdot 8 \\
0 \cdot 8 \\
0 \cdot 8-0 \cdot 9 \\
0 \cdot 9-0 \cdot 95 \\
0 \cdot 7-0 \cdot 8\end{array}$ \\
\hline
\end{tabular}

\section{Clinical Investigations and Results}

Four-point Assays for Total Gonadotrophins on Urine from Normal Subjects. Assays using a $(2+2)$ design and 5 mice per group were performed on extracts of urine from healthy subjects, both adults and children. All the assays were statistically valid and results are shown in Table 8.

Excretion of Total Urinary Gonadotrophins in Normal Men and Women. Pools of urine comprising 2 to 6 complete 24-hour collections from each subject were assayed for gonadotrophic activity using a 3 (standard) +1 (unknown) design with 5 mice per group.

In 12 healthy men aged 18 to 40 years, total urinary gonadotrophins ranged from 3.8 to $18 \cdot 1 \mathrm{mg}$. I.R.P./24 hr. with a mean of $7 \cdot 7$. Eight healthy women aged 18 to 35 years were studied, and 24-hour urine collections were made at random during the cycle and pooled for each subject, no attempt being made to follow changes during individual menstrual cycles. The mean excretion of total urinary gonadotrophins was $4 \cdot 9 \mathrm{mg}$. I.R.P. $/ 24 \mathrm{hr}$. with a range of $2 \cdot 7$ to $7 \cdot 05$.

Effect of Extracts from Urine of Children on Assay of Total Urinary Gonadotrophin. In order to determine whether children's urine extracted by the method described contained an inhibitor to gonadotrophic activity, extracts of urine were added to a standard amount of $1.0 \mathrm{mg}$. LAB-G as shown in Table 9 , and the mixture was assayed according to the usual procedure.

The uterine weights obtained are shown in Table 9. The extracts alone did not cause any increase in uterine weight. When combined with LAB-G they did not significantly alter the response to $1.0 \mathrm{mg}$. LAB-G. None of the mice showed evidence of toxicity in this experiment. There was no evidence to suggest that an inhibitor was present in extracts prepared from children's urine by the method already described.

Total Urinary Gonadotrophin Excretion in Children Without Endocrinological Abnormalities. The majority of assays were of 4 (standard) +1 (unknown) design, using 5 mice at each dose level for the standard and 3 to 5 for the unknown, depending on the amount of extract available. The limit of sensitivity for each assay varied according to the amount of extract injected and the sensitivity of the mice. If the largest dose of extract injected failed to cause a positive response, the result was recorded as 'undetectable activity and less than $x$ mg. I.R.P./24 hr.', the value of $x$ varying with the sizes of the responses to the standard and the amount of extract injected. No toxic effects were observed when purified extracts equivalent to a 24-hour urine collection were injected into each mouse.

TABLE 9

EFFECT OF EXTRACTS FROM CHILDREN'S URINE ON TOTAL GONADOTROPHIC ACTIVITY

\begin{tabular}{|c|c|c|c|c|c|}
\hline \multirow{2}{*}{ Test } & \multicolumn{2}{|r|}{ Material Assayed } & \multirow{2}{*}{$\begin{array}{l}\text { Number } \\
\text { of Mice } \\
\text { Tested }\end{array}$} & \multirow{2}{*}{$\begin{array}{c}\text { Mean Uterine } \\
\text { Weight } \\
\text { (mg. } \pm \text { S.E.M.) }\end{array}$} & \multirow{2}{*}{$\mathbf{p}$} \\
\hline & $\begin{array}{c}\text { LAB-G } \\
\text { Added (mg.) }\end{array}$ & Urinary Extract & & & \\
\hline $\begin{array}{l}1 \\
2\end{array}$ & $\begin{array}{l}1 \cdot 0 \\
1 \cdot 0\end{array}$ & \multirow{6}{*}{ 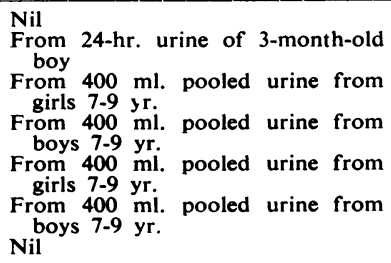 } & $\begin{array}{r}10 \\
5\end{array}$ & $\begin{array}{r}10.3 \pm 0.90 \\
9.6 \pm 1.47\end{array}$ & \multirow{6}{*}{$\begin{array}{c}\text { For (1) and (2) } \\
\simeq 0.3 \\
\text { For }(1) \text { and (3) } \\
\simeq 0.25 \\
\text { For }(1) \text { and (4) } \\
\simeq 0.4\end{array}$} \\
\hline 3 & $1 \cdot 0$ & & 10 & $9 \cdot 1 \pm 1 \cdot 18$ & \\
\hline 4 & $1 \cdot 0$ & & 10 & $10.6 \pm 0.98$ & \\
\hline 5 & Nil & & 5 & $4 \cdot 1 \pm 0 \cdot 34$ & \\
\hline 6 & Nil & & 5 & $4 \cdot 5 \pm 0 \cdot 41$ & \\
\hline 7 & $\mathrm{Nil}$ & & 5 & $4 \cdot 0 \pm 0 \cdot 35$ & \\
\hline
\end{tabular}


TABLE 10

EXCRETION OF TOTAL URINARY GONADOTROPHIN IN BOYS

\begin{tabular}{|c|c|c|c|c|c|}
\hline \multirow[t]{2}{*}{ Patient } & \multirow{2}{*}{$\begin{array}{l}\text { Chronological } \\
\text { Age (yr.) }\end{array}$} & \multicolumn{2}{|c|}{$\begin{array}{l}\text { Genital and Secondary } \\
\text { Sex Character Rating }\end{array}$} & \multirow{2}{*}{$\begin{array}{c}\text { Total Urinary } \\
\text { Gonadotrophin } \\
\text { (mg. I.R.P./24 hr.) }\end{array}$} & \multirow{2}{*}{$\begin{array}{l}\text { Fiducial Limits } \\
\quad(p=0.95)\end{array}$} \\
\hline & & Genital & Pubic Hair & & \\
\hline $\begin{array}{l}\text { P.L. } \\
\text { R.A. } \\
\text { P.W. } \\
\text { R.W. } \\
\text { P.W. } \\
\text { G.S. } \\
\text { G.H. } \\
\text { D.S. } \\
\text { M.G. } \\
\text { L.B. } \\
\text { S.B. } \\
\text { M.P. } \\
\text { M.J. } \\
\text { M.Hu. } \\
\text { M.H. } \\
\text { M.R. } \\
\text { A.S. } \\
\text { R.S. } \\
\text { A.W. } \\
\text { G.S. } \\
\text { A.M. } \\
\text { L.L. } \\
\text { G.M. } \\
\text { R.D. } \\
\text { I.B. } \\
\text { P.F. } \\
\text { C.M. } \\
\text { A.H. } \\
\text { I.W. } \\
\text { A.G. } \\
\text { A.B. } \\
\text { D.F. } \\
\text { A.J. } \\
\text { R.D. } \\
\text { P.B. } \\
\text { A.M. } \\
\text { J.P. } \\
\text { R.O. } \\
\text { K.B. } \\
\text { J.B. } \\
\text { M.S. } \\
\text { S.B. } \\
\text { S.H. } \\
\text { J.S. } \\
\text { C.L. } \\
\text { P.D. }\end{array}$ & $\begin{array}{ll} & 3 / 12 \\
& 6 / 12 \\
9 / 12 & 9 / 12 \\
1 & 11 / 12 \\
3 & 10 / 12 \\
4 & 6 / 12 \\
5 & 2 / 12 \\
5 & 2 / 12 \\
5 & 6 / 12 \\
5 & 9 / 12 \\
6 & \\
7 & \\
7 & \\
7 & \\
7 & 3 / 12 \\
7 & 3 / 12 \\
7 & 4 / 12 \\
7 & 9 / 12 \\
8 & 3 / 12 \\
8 & 5 / 12 \\
8 & 6 / 12 \\
8 & 6 / 12 \\
9 & \\
9 & 6 / 12 \\
9 & 7 / 12 \\
9 & 9 / 12 \\
9 & 11 / 12 \\
10 & \\
10 & 2 / 12 \\
11 & \\
11 & 2 / 12 \\
11 & 9 / 12 \\
12 & \\
12 & 2 / 12 \\
12 & 2 / 12 \\
12 & 7 / 12 \\
13 & \\
13 & \\
13 & \\
13 & 1 / 12 \\
13 & 6 / 12 \\
13 & 9 / 12 \\
14 & 6 / 12 \\
14 & 7 / 12 \\
14 & 8 / 12 \\
15 & \\
15 & \end{array}$ & 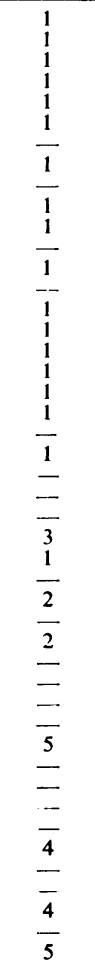 & $\begin{array}{l}1 \\
1 \\
1 \\
\frac{1}{1} \\
\frac{1}{1} \\
\frac{1}{1} \\
\frac{1}{1} \\
\frac{1}{1} \\
\frac{1}{1} \\
\frac{-}{1} \\
\frac{1}{1} \\
\frac{1}{1} \\
\frac{1}{4} \\
\frac{-}{4} \\
\end{array}$ & $\begin{array}{l}<0.3 \\
<0.3 \\
0.92 \\
<0.3 \\
0.76 \\
<0.7 \\
<0.5 \\
<0.3 \\
0.59 \\
<0.4 \\
<0.3 \\
<0.4 \\
<0.3 \\
0.14 \\
<0.04 \\
<0.7 \\
<0.5 \\
0.76 \\
0.77 \\
0.80 \\
0.80 \\
0.94 \\
<0.3 \\
0.32 \\
<0.5 \\
<0.4 \\
<0.3 \\
0.43 \\
0.67 \\
<0.5 \\
<0.4 \\
<0.4 \\
6.72 \\
0.31 \\
2.90 \\
1.86 \\
<0.4 \\
4.23 \\
<0.5 \\
1.36 \\
1.05 \\
0.59 \\
1.02 \\
0.58 \\
0.77 \\
3.30\end{array}$ & $\begin{array}{l}4 \cdot 43-9 \cdot 65 \\
0 \cdot 09-0 \cdot 49 \\
2 \cdot 14-4 \cdot 53 \\
1 \cdot 32-2 \cdot 65 \\
\\
2 \cdot 32-7 \cdot 52 \\
0 \cdot 66-2 \cdot 28 \\
0 \cdot 68-1 \cdot 62 \\
0 \cdot 28-0 \cdot 88 \\
0 \cdot 77-1 \cdot 34 \\
0 \cdot 34-0 \cdot 80 \\
0 \cdot 52-1 \cdot 12 \\
2 \cdot 42-4 \cdot 72\end{array}$ \\
\hline
\end{tabular}

— indicates 'not determined'.

Assays were performed on urine from 46 boys and 58 girls aged 3 months to 15 years 8 months. The results are given in Tables 10 and 11, and are shown diagrammatically in Fig. 5.

Measurable activity was obtained as early as 9 months in a boy and 1 year 10 months in a girl.

Serial determinations were made on 2- or 3-day pools of complete 24-hour urines, as follows.

(a). 5 premenarchal girls (M.M., L.O., A.P., A.H., and Y.Y.) all of whom had pre-adolescent secondary sex character rating.

(b). 1 post-menarchal girl (M.D.) with breast development rating, 3; and pubic hair rating, 4.

(c). 1 pre-adolescent boy (A.W.).

(d). 1 adolescent boy (J.S.) with genital development rating, 4; and pubic hair rating, 4 .

In Y.Y. (7 yr. $10 \mathrm{mth}$. of age) no gonadotrophin activity was detected throughout a 30-day period of study. Results for M.M., L.O., A.H., M.D., A.W., A.P., and J.S. are shown in Fig. 6.
Urinary Excretion of Luteinizing Hormone by Children without Endocrinological Abnormalities. A series of assays was performed on pooled collections of urine from children of various age-groups. There were 6 to 8 children in each age-group, and the results are shown in Table 12. Toxic reactions were produced with urine from the higher age-groups, both boys and girls, even though the amount of extract injected was generally equivalent to less than 24-hour urine. In the lower age-groups the toxic effect (if any) was much less marked, even though the amount of extract injected into each rat exceeded the equivalent of 24-hour urine.

Assays were also performed on individual pools of 24-hour urines obtained from 12 children: 4 assays were invalid because of significant deviation from parallelism and 2 assays showed no depletion of ovarian ascorbic acid at the highest dose injected. Results of valid assays are shown in Table 12. 
URINARY EXCRETION OF GONADOTROPHINS

TABLE 11

EXCRETION OF TOTAL URINARY GONADOTROPHIN IN GIRLS

\begin{tabular}{|c|c|c|c|c|c|}
\hline \multirow{2}{*}{ Patient } & \multirow{2}{*}{ Age (yr.) } & \multicolumn{2}{|c|}{ Secondary Sex Character Rating } & \multirow{2}{*}{$\begin{array}{l}\text { Total Urinary } \\
\text { Gonadotrophin } \\
\text { (mg. I.R.P./24 hr.) }\end{array}$} & \multirow{2}{*}{$\begin{array}{l}\text { Fiducial Limits } \\
\quad(p=0.95)\end{array}$} \\
\hline & & $\begin{array}{c}\text { Breast } \\
\text { Development }\end{array}$ & $\begin{array}{l}\text { Pubic } \\
\text { Hair }\end{array}$ & & \\
\hline $\begin{array}{l}\text { M.M. } \\
\text { L.O. } \\
\text { L.H. } \\
\text { A.S. } \\
\text { S.E. } \\
\text { C.E. } \\
\text { C.O. } \\
\text { A.P. } \\
\text { A.A. } \\
\text { O.C. } \\
\text { S.O. } \\
\text { S.C. } \\
\text { K.W. } \\
\text { Y.Y. } \\
\text { B.C. } \\
\text { B.O. } \\
\text { L.N. } \\
\text { B.D. } \\
\text { S.R. } \\
\text { L.S. } \\
\text { I.C. } \\
\text { C.B. } \\
\text { M.W. } \\
\text { K.F. } \\
\text { J.M. } \\
\text { M.O. } \\
\text { A.H. } \\
\text { E.E. } \\
\text { P.B. } \\
\text { C.B. } \\
\text { I.S. } \\
\text { D.C. } \\
\text { Y.B. } \\
\text { J.B. } \\
\text { M.A. } \\
\text { C.E. } \\
\text { D.H. } \\
\text { J.G. } \\
\text { P.B. } \\
\text { P.O. } \\
\text { M.K. } \\
\text { S.B. } \\
\text { C.W. } \\
\text { L.W. } \\
\text { C.P. } \\
\text { C.R. } \\
\text { H.R. } \\
\text { P.W. } \\
\text { M.D. } \\
\text { A.I. } \\
\text { A.L. } \\
\text { J.R. } \\
\text { E.G. } \\
\text { M.B. } \\
\text { C.W. } \\
\text { D.H. } \\
\text { B.S. }\end{array}$ & $\begin{array}{ll}1 & 10 / 12 \\
2 & 2 / 12 \\
3 & 2 / 12 \\
3 & 2 / 12 \\
3 & 4 / 12 \\
4 & \\
5 & 1 / 12 \\
5 & 3 / 12 \\
5 & 8 / 12 \\
5 & 11 / 12 \\
6 & 3 / 12 \\
6 & 5 / 12 \\
6 & 7 / 12 \\
6 & 11 / 12 \\
7 & 1 / 12 \\
7 & 2 / 12 \\
7 & 2 / 12 \\
7 & 6 / 12 \\
7 & 11 / 12 \\
8 & 2 / 12 \\
8 & 4 / 12 \\
8 & 6 / 12 \\
8 & 10 / 12 \\
9 & \\
9 & 3 / 12 \\
9 & 5 / 12 \\
9 & 5 / 12 \\
9 & 5 / 12 \\
9 & 5 / 112 \\
9 & 7 / 12 \\
9 & 10 / 12 \\
10 & \\
10 & \\
10 & 1 / 12 \\
10 & 2 / 12 \\
10 & 3 / 12 \\
10 & 4 / 12 \\
10 & 6 / 12 \\
10 & 8 / 12 \\
10 & 8 / 12 \\
10 & 9 / 12 \\
11 & 2 / 12 \\
11 & 10 / 12 \\
12 & \\
12 & 1 / 12 \\
12 & 2 / 12 \\
12 & 3 / 12 \\
12 & 3 / 12 \\
12 & 5 / 12 \\
12 & 9 / 12 \\
13 & \\
13 & 4 / 12 \\
13 & 11 / 112 \\
14 & \\
14 & 4 / 12 \\
14 & 111 / 12 \\
15 & \\
15 & 8 / 12 \\
& \end{array}$ & 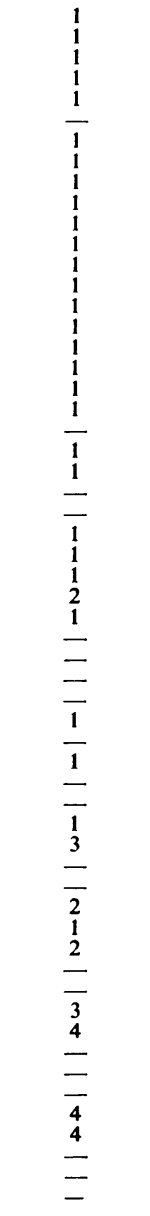 & 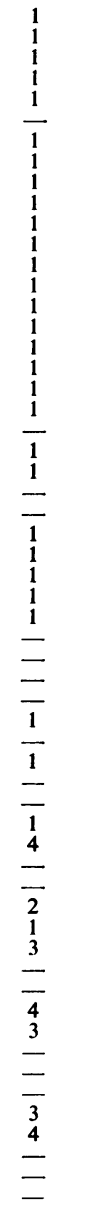 & 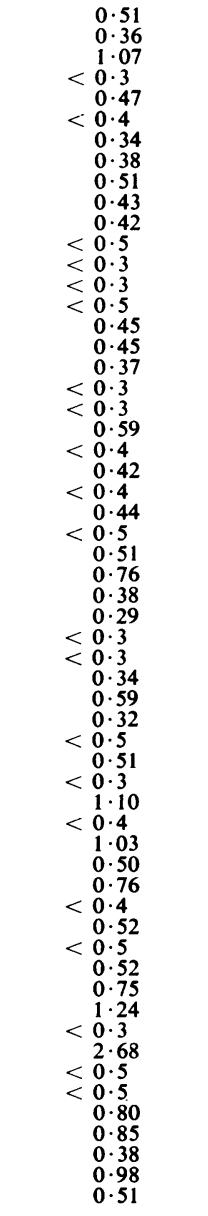 & $\begin{array}{l}\text { } 0 \cdot 26-0 \cdot 62 \\
0 \cdot 23-0 \cdot 77 \\
0 \cdot 14-0 \cdot 55 \\
\\
0 \cdot 62-0 \cdot 85 \\
0 \cdot 26-0 \cdot 80 \\
0 \cdot 23-0 \cdot 78 \\
0 \cdot 28-0 \cdot 91 \\
0 \cdot 50-1 \cdot 17 \\
0 \cdot 18-0 \cdot 57 \\
0 \cdot 16-0 \cdot 52 \\
\\
0 \cdot 17-0 \cdot 55 \\
0 \cdot 43-0 \cdot 73 \\
0 \cdot 15-0 \cdot 51 \\
0 \cdot 34-0 \cdot 91 \\
0 \cdot 82-1 \cdot 71 \\
0 \cdot 66-1 \cdot 56 \\
0 \cdot 15-0 \cdot 93 \\
0 \cdot 56-1 \cdot 08 \\
0 \cdot 26-0 \cdot 88 \\
0 \cdot 34-0 \cdot 75 \\
0 \cdot 41-1 \cdot 34 \\
0 \cdot 55-2 \cdot 54 \\
1 \cdot 63-4 \cdot 18 \\
0 \cdot 53-1 \cdot 16 \\
0 \cdot 40-1 \cdot 27 \\
0 \cdot 18-0 \cdot 57 \\
0 \cdot 73-1 \cdot 52 \\
0 \cdot 29-1 \cdot 89\end{array}$ \\
\hline
\end{tabular}

— indicates 'not determined'.

\section{Discussion}

The immature mouse uterus has been used as a reliable and sensitive end-point for the bio-assay of total urinary gonadotrophins. The extract has been administered as a single injection following pretreatment of the mice with a sub-threshold dose of HCG.

From results published by other investigators (Borth et al., 1961), it is clear that many strains of mice have a greater sensitivity to human menopausal gonadotrophin than the strain available for the present study, so that the method described could have even greater sensitivity.

The mechanism of potentiation with HCG remains obscure. The fact that simultaneous administration of HCG and LAB-G did not show any synergistic interaction raises the possibility that this phenomenon is only demonstrable when HCG is administered before an injection containing follicle-stimulating hormone. This aspect appears to have been overlooked in most studies on synergism because assays extending over several days have been used (Evans and Simpson, 1950). 


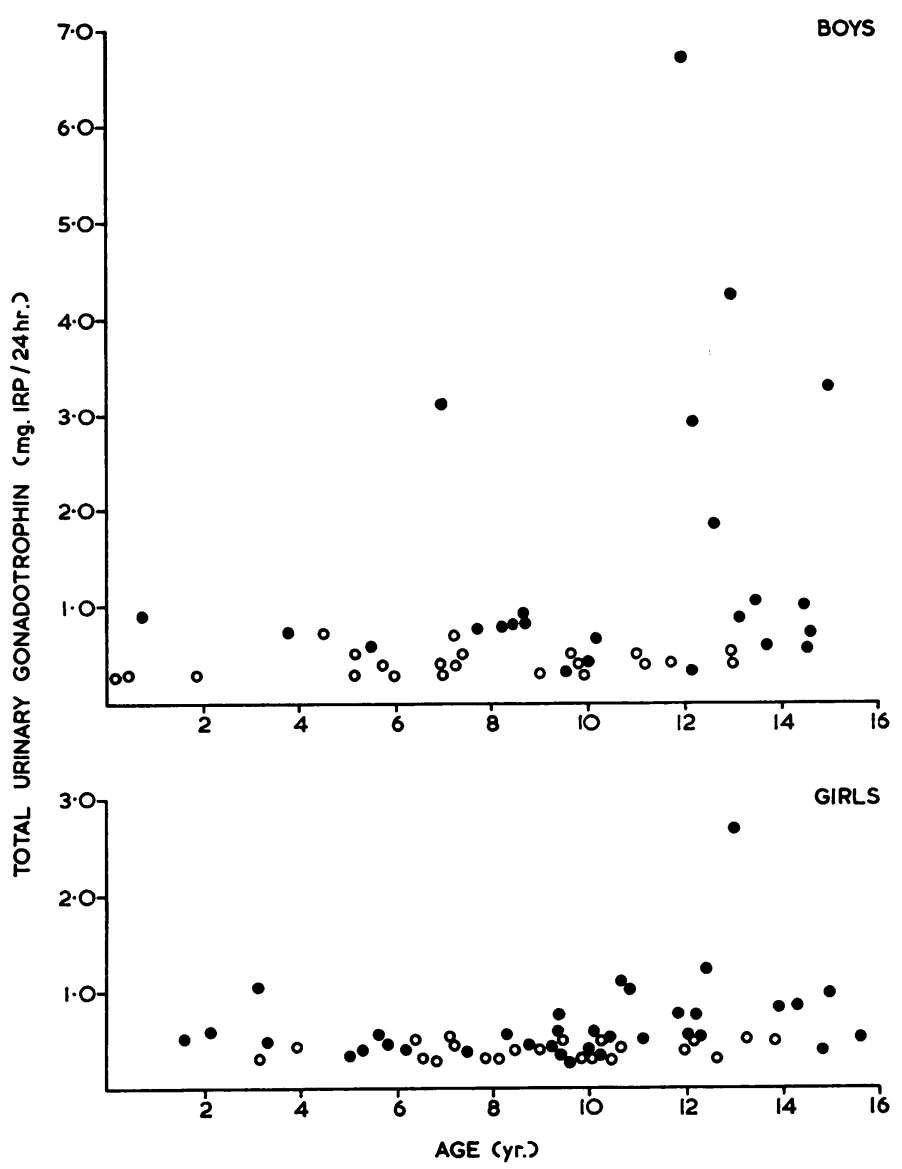

FIG. 5. - Total urinary gonadotrophin excretion in boys and girls.

Total urinary gonadotrophin in mg. I.R.P./24 hours.

o No gonadotrophin detected, and excretion is less than the value indicated.

The extraction and assay used in the present study gave reproducible results of reasonable accuracy. Recovery experiments showed results similar to those reported by Loraine and Brown (1959) and Heinrichs and Eulefeld (1960). This type of recovery can be criticized (Albert, 1956), because it is not certain that gonadotrophin added to raw urine or extracts will behave in the same way as it did initially in the original urine. The four-point assays with extracts of urine from pre-adolescent children and adults showed satisfactory similarity of response with the laboratory standard LAB-G which was obtained from post-menopausal urine. The levels found in men and women were similar to those reported by other investigators who used similar extraction procedures (Apostolakis, 1961; Brown, 1959a, b; Loraine and Bell, 1963).

Of 33 boys aged less than 12 years, measurable excretions of total urinary gonadotrophins were found in 13 of them, using pools of 24-hour urines from single subjects. The youngest boy with detectable amounts was only 9 months. In older boys aged 12 to 15 years, total urinary gonadotrophin was measurable in 12 of the 14 investigated. Serial determinations in a pre-adolescent boy (A.W.) indicated intermittent and/or considerable fluctuation in excretion, whereas a fairly constant excretion was found in an older adolescent boy (J.S.). Certainly below the age of 12 years, no clinical significance can be attached to a failure to demonstrate gonadotrophin in the urine, though a positive result may be of value.

Similar results were found in the girls though levels were generally lower than in the boys. Detectable excretion was found in $75 \%$ of the girls in the 0-6 year age-group. The more frequent undetectable levels (compared with boys) in the older age-groups may be due to the greater fluctua- 


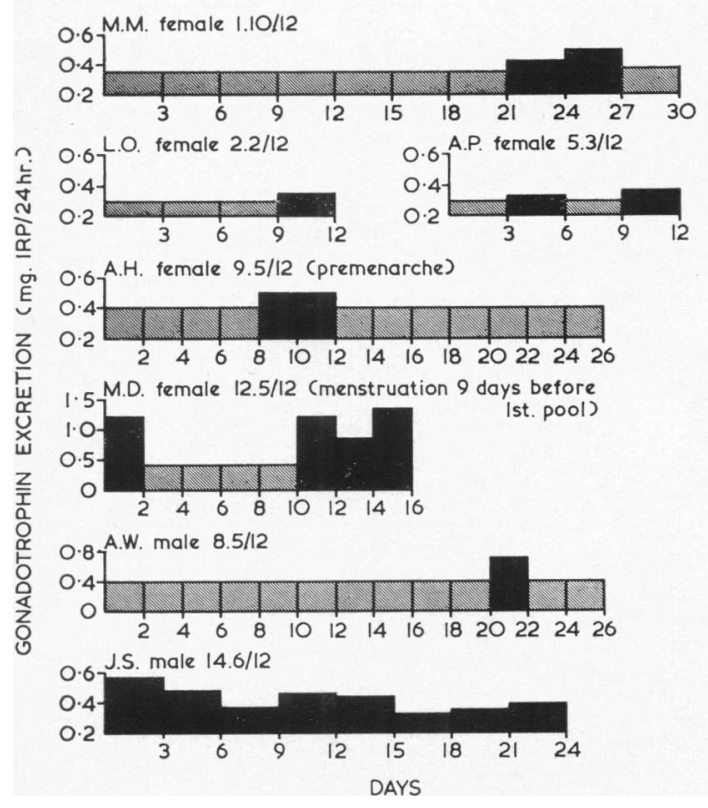

Fig, 6.-Serial determinations of the excretion of total urinary gonadotrophin in 7 children. Results are in mg. I.R.P./24 hours. The solid b'ack area is total urinary gonadotrophin.

The shaded area indicates no gonadotrophin, and excretion less than the value indicated.

tion in excretion as indicated by the serial determinations. Intermittent excretion was seen in M.M. aged 1 year and 10 months, and also in the postmenarchal subject studied (M.D., 12 years and 5 months). As with the boys, assays of total urinary gonadotrophin must be interpreted with these limitations in mind. In general, results for total

TABLE 12

ASSAY OF LUTEINIZING HORMONE IN CHILDREN'S URINE

\begin{tabular}{|c|c|c|c|c|}
\hline Patient & Age (yr.) & $\begin{array}{l}\text { Excretion of } \\
\text { Luteinizing } \\
\text { Hormone } \\
\text { ( } \mu \text { g. NIH- } \\
\text { LH/24 hr.) }\end{array}$ & $\begin{array}{c}\text { Fiducial } \\
\text { Limits } \\
(p=0.95)\end{array}$ & $\lambda$ \\
\hline $\begin{array}{r}\text { Boys: } \\
\text { Pool } \\
\text { Pool } \\
\text { Pool } \\
\text { Pool } \\
\text { C.J. } \\
\text { A.B. }\end{array}$ & $\begin{array}{c}0-6 \\
6-8 \\
10-12 \\
12-15 \\
2 \\
11\end{array}$ & $\begin{array}{l}0 \cdot 89 \\
0 \cdot 26 \\
1 \cdot 14 \\
6 \cdot 59 \\
1 \cdot 68 \\
2 \cdot 30\end{array}$ & $\begin{array}{l}0 \cdot 35-1 \cdot 47 \\
0 \cdot 04-0 \cdot 53 \\
0 \cdot 29-2 \cdot 16 \\
2 \cdot 38-11 \cdot 70 \\
0 \cdot 52-2 \cdot 92 \\
1 \cdot 04-3 \cdot 98\end{array}$ & $\begin{array}{l}0 \cdot 28 \\
0 \cdot 34 \\
0 \cdot 33 \\
0 \cdot 34 \\
0 \cdot 25 \\
0 \cdot 24\end{array}$ \\
\hline $\begin{array}{l}\text { Gir/s: } \\
\text { Pool }\end{array}$ & $0-6$ & \multicolumn{3}{|c|}{$\begin{array}{c}\text { Invalid assay: significant deviation } \\
\text { from parallelism }\end{array}$} \\
\hline $\begin{array}{l}\text { Pool } \\
\text { Pool } \\
\text { Pool } \\
\text { M.M. } \\
\text { L.H. } \\
\text { S.B. } \\
\text { Y.B. } \\
\text { A.L. }\end{array}$ & $\begin{array}{c}6-8 \\
10-12 \\
12-15 \\
2 \\
32 / 12 \\
11 \\
12 \\
136 / 12\end{array}$ & $\begin{array}{r}0.25 \\
1.50 \\
2.46 \\
1.06 \\
<0.5 \\
1.98 \\
2.09 \\
<0.5\end{array}$ & $\begin{array}{c}0 \cdot 06-0 \cdot 52 \\
0 \cdot 54-2 \cdot 55 \\
0 \cdot 95-4 \cdot 35 \\
0 \cdot 27-1 \cdot 97 \\
1 \cdot 11-3 \cdot 56 \\
1 \cdot 14-3 \cdot 10 \\
\quad\end{array}$ & $\begin{array}{l}0 \cdot 25 \\
0 \cdot 31 \\
0 \cdot 34 \\
0 \cdot 29 \\
0 \cdot 21 \\
0 \cdot 25 \\
-\end{array}$ \\
\hline
\end{tabular}

gonadotrophin excretion in children have not been related to a reference preparation. Brown (1958) studied children from 10 to 15 years and gave his results in mg. HMG 20/1. urine. He used pools composed of random samples of urine, so that his results cannot be interpreted in terms of individual 24-hour excretions. In contrast to the present results, he found more gonadotrophin in girls than in boys, his results for boys being similar to the ones reported in this study.

The ovarian ascorbic acid depletion assay of urinary extracts containing low levels of LH presented considerable difficulties. The large amount of extract that had to be injected produced toxic effects and resulted in death of some of the animals. The rather flat slope of the dose-response curve usually resulted in an unsatisfactory index of precision and wide fiducial limits. This is in accord with the results published by Schmidt-Elmendorff and Loraine (1962), though Bell, Mukerji, and Loraine (1964) have recently published a modification of the method overcoming all these difficulties.

In pooled urine from boys, measurable LH was found in all age-groups, the amount increasing with age. Similar results were seen in girls but the assay on the 0 to 6 year age-group was invalid. The results suggest that there may be a correlation between the onset of puberty and the excretion of $\mathrm{LH}$, and this would be worth further investigation using the improved method of Bell et al. (1964).

No evidence suggesting a gonadotrophin inhibitor in children's urine has been found. The method of extraction and purification used in the present study is different from that of Soffer et al. $(1961,1962)$, and perhaps this explains the conflicting results.

The values, in terms of a reference preparation for gonadotrophin excretion in normal children, will enable the results found in pathological states, e.g. precocious puberty, to be better evaluated. Failure to demonstrate gonadotrophin in the urine of any particular child must be interpreted in the light of the findings in the normal child, and the other clinical and laboratory findings must be taken carefully into account.

The excretion of total urinary gonadotrophin was studied in endocrinologically normal boys and girls, and the results were expressed in terms of a standard reference preparation. Low amounts were frequently found in children's urine even before the age of puberty, the youngest boy being 9 months and girl 1 year and 10 months. The inability to detect gonadotrophin in any particular child must be interpreted with caution and in the light of the other clinical and laboratory findings. No inhibitor to 
urinary gonadotrophic activity could be demonstrated with the method of extraction and purification used in this study.

A method specific for luteinizing hormone was applied to pools of children's urine, and detectable amounts were present both before and after puberty. There was considerable variation in excretion among the few individuals studied separately.

We thank the Consultant Staff of The Hospital for Sick Children for permission to study their patients. The co-operation of the Nursing Staff in the collection of hundreds of 24-hour urines is greatly valued.

Dr. A. G. C. Renwick kindly helped in obtaining urine from patients at Tadworth Court. Mr. G. Crabb and Mr. D. Trafford gave invaluable technical assistance. One of us (W.H.E.F.) is indebted to The Joint Research Board of The Hospital for Sick Children and The Institute of Child Health for financial assistance during this study.

\section{REFERENCES}

Albert, A. (1956). Human urinary gonadotrophin. Recent Progr. Hormone Res., 12, 227.

—-, Kobi, J., Leiferman, J., and Derner, I. (1961). Purification of pituitary gonadotropin from urine of normal men. J. clin. Endocr., 21, 1.

Apostolakis, M. (1961). Experimentalle Grundlügen und klinische Bedeutung der Forschung auf dem Gebiet der menschlichen hypophysären Gonadotropine. Klin. Wschr., 39, 453.

Bell, E. T., Mukerji, S., and Loraine, J. A. (1964). A new bioassay method for luteinizing hormone depending on the depletion of rat ovarian cholesterol. J. Endocr., 28, 321.

Borth, R., Diczfalusy, E., and Heinrichs, H. D. (1957). Grundlagen der statistischen Auswertung biologischer Bestimmungen. Arch Gynäk., 188, 497.

_- Lunenfeld, B., and Menzi, A. (1961). Comparison of kaolinacetone methods. In Human Pituitary Gonadotropins, ed. A. Albert, p. 13. Charles C. Thomas, Springfield, Illinois.

Brown, P. S. (1958). Human urinary gonadotrophins. I. In relation to puberty. J. Endocr., 17, 329.

- (1959a). Human urinary gonadotrophins. II. In relatior. to the menstrual cycle, secondary amenorrhoea and the response to oestrogen. ibid., 18, 46.

(1959b). Urinary gonadotrophins in normal men. Acta endocr. (Kbh.), 32, 272.

—- and Billewicz, W. Z. (1962). The response of immature mice to mixtures of gonadotrophins. J. Endocr., 24, 65 .

Carletti, B., and Kehyayan, E. (1962a). L'eliminazione urinaria delle gonadotropine nell 'età infantile. Studio di un gruppo di sogget ti di 3-6 anni. Minerva pediat., 14, 21.

- - _ - (1962b). Caratteristiche biologiche delle gonadotropine urinarie nell 'infanzia. Confronto fra gruppi di bambini di diversa età. ibid., 14, 786.

-,,- and Perletti, L. (1961). Studio sulle caratteristiche biologiche e chimiche delle gonadotropine urinarie nell 'età infantile. Folia endocr. (Roma), 14, 388.

Catchpole, H. R., and Greulich, W. W. (1943). The excretion of gonadotrophic hormone by prepuberal and adolescent girls. J. clin. Invest., 22, 799.

$-\cdots,-\frac{1}{-}$, and Sollenberger, R. T. (1938). Urinary excretion of follicle stimulating hormone in young and adolescent boys. Amer. J. Physiol., 123, 32.

Claringbold, P. J., and Lamond, D. R. (1957). Optimum conditions for the biological assay of gonadotrophins. J. Endocr., 16, 86.

Evans, H. M., and Simpson, M. E. (1950). Physiology of the gonadotrophins. In The Hormones, Physiology, Chemistry and Applications, Vol. II, ed. G. Pincus and K. V. Thimann, p. 351. Academic Press, New York.

Gaddum, J. H. (1953a). Bioassays and mathematics. Pharmacol. Rev., 5, 87.

_- (1953b). Simplified mathematics for bioassays. J. Pharm. Pharmacol., 5, 345.

Greulich, W. W., Dorfman, R. I., Catchpole, H. R., Solomon, C. I., and Culotta, C. S. (1942). Somatic and endocrine studies of puberal and adolescent boys. Monogr. Soc. Res. Child. Developm. 7 , No. 3.

Heinrichs, H. D., and Eulefeld, F. (1960). Untersuchungen über die Extraktion von hypophysärem Gonadotropin aus Urin. Acta endocr. (Kbh.), Suppl. 53.

Johnsen, S. G. (1959). A clinical routine-method for the quantitative determination of gonadotrophins in 24-hour urine samples. II : Normal values for men and women at all age groups from prepuberty to senescence. ibid., 31, 209.

Katzman, P. A., and Doisy, E. A. (1933). A quantitative procedure for determining normal excreticn of prolan. Proc. Soc. exp. Biol. (N.Y.), 30, 1188.

- - - (1934). The quantitative determination of small amounts of gonadotropic material. J. biol. Chem., 106, 125.

Kehyayan, E. (1960). L'eliminazione urinaria delle gonadotropine dagli 8 ai 14 anni. Minerva pediat., 12, 1601.

Klinefelter, H. F., Jr., Albright, F., and Gricwold, G. C. (1943) Experience with a quantitative test for normal or decreased amounts of follicle stimulating hormone in the urine in endocrinological diagnosis. J. clin. Endocr., 3, 529.

Knappe, G., Dörner, G., and Stahl, F. (1961). Nachweis hypophysärer Gonadotropine im Harn von Kindern. Klin. Wschr., 39 971.

Lamond, D. R., and Claringbold, P. J. (1958). Joint action of gonadotrophic substances. J. Endocr., 16, 298.

Landau, B., Schwartz, H. S., and Soffer, L. J. (1960). Presence of a gonadotrophin-inhibiting factor in urine of young children. Metabolism, 9, 85

Loraine, J. A., and Bell, E. T. (1963). Hormone excretion during the normal menstrual cycle. Lancet, 1, 1340.

, and Brown, J. B. (1959). A method for the quantitative determination of gonadotrophins in the urine of non-pregnant human subjects. J. Endocr., 18, 77.

McArthur, J. W., Ingersoll, F. M., and Worcester, J. (1958). Urinary excretion of interstitial-cell stimulating hormone by normal males and females of various ages. J. clin. Endocr., 18, 460.

Minkina, A. I. (1961). Some findings on the biological activity and chemical composition of the gonadotrophic hormones in ontogenesis. Proc. 5th Int. Congr. Biochem., Moscow, 9, 320.

Morató-Manaro, J., Cerviño, J. M., and Maggiolo, J. (1960). A method of determining interstitial-cell stimulating hormone in urine: some results in normal and pathological cases. In Ciba Foundation Colloquia on Endocrinology, Vol. 13, p. 238. Churchill, London.

Nathanson, I. T., Towne, L. E., and Aub, J. C. (1941). Normal excretion of sex hormones in childhood. Endocrinology, 28, 851 .

Pedersen-Bjergaard, K., and Tønnesen, M. (1948a). Oestrogenic, androgenic and gonadotrophic substances in the urine of normal women. Sex hormone analyses I. Acta endocr. (Kbh.), 1, 38. - (1948b). Sex hormone analyses II. The excretion of sexual hormones by normal males, impotent males, polyarthritics and prostatics. Acta med. scand., Suppl. 213, 284.

Rosemberg, E. (1960). Urinary gonadotropin excretion measured by the mouse uterine response, employing estrone as the standard reference material. J. clin. Endocr., 20, 306.

(1961). End points of sensitivity. In Human Pituitary Gonadotropins, ed. A. Albert, p. 110. Charles C. Thomas, Springfield, Illinois.

Saethre, H. (1933). Uber die Ausscheidung von Prolan im Harn in der Involutionsperiode bzw. im senium. Klin. Wschr., 12, 1727.

Schmidt-Elmendorff, H., and Loraine, J. A. (1962). Some observations on the ovarian ascorbic acid depletion method as a test for luteinizing hormone activity. J. Endocr., 23, 413.

Schörcher, F. (1931). Zur Physiologie und Pathologie der Prolanausscheidung im Harn bei Kindern und Jugendlichen. Klin. Wschr., 10, 2221.

Schwenk, A., and Ohndorf, H. (1957). Untersuchungen zur Endokrinologie der Pubertät. I. Mitteilung: Die Urinausscheidung der hypophysären Gonadotropine in der männlichen und weiblichen Pubertät. Z. Kinderheilk, 79, 645.

Soffer, L. J., Futterweit, W., and Salvaneschi, J. (1961). A gonadotropin-inhibiting substance in the urine of normal young children. J. clin. Endocr., 21, 1267.

- Salvaneschi, J., and Futterweit, W. (1962). A gonadotropininhibiting substance in the urine of normal subjects. ibid., 22, 532.

Tanner, J. M. (1955). Growth at Adolescence, p. 25 et seq. Blackwell, Oxford. 